$\begin{array}{ll} & \text { Etnográfica } \\ \text { etnográfica } & \text { Revista do Centro em Rede de Investigação em }\end{array}$

Antropologia

vol. 14 (3) | 2010

Vol. 14 (3)

\title{
Work, wage and consumption: valuing and displaying among manufacturing workers
}

Valor e expressão do trabalho, do salário e do consumo entre mulheres operárias

\section{Emília Margarida Marques}

\section{(2) OpenEdition}

\section{Journals}

\section{Edição electrónica}

URL: https://journals.openedition.org/etnografica/197

DOI: 10.4000/etnografica.197

ISSN: 2182-2891

\section{Editora}

Centro em Rede de Investigação em Antropologia

\section{Edição impressa}

Data de publição: 1 outubro 2010

Paginação: 527-547

ISSN: 0873-6561

\section{Refêrencia eletrónica}

Emília Margarida Marques, «Work, wage and consumption: valuing and displaying among

manufacturing workers», Etnográfica [Online], vol. 14 (3) | 2010, posto online no dia 21 outubro 2011, consultado o 12 fevereiro 2022. URL: http://journals.openedition.org/etnografica/197 ; DOI: https:// doi.org/10.4000/etnografica.197

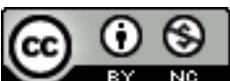

Etnográfica is licensed under a Creative Commons Attribution-NonCommercial 4.0 International License. 


\title{
Work, wage and consumption: valuing and displaying among manufacturing workers
}

\section{Emília Margarida Marques}

\begin{abstract}
When a former female manual worker decides to put on gel nails soon after losing the job that had prevented her from making up her hands (as someone in my fieldwork has recently done), it could be tempting to see a shift from a constrained worker identity to an unbound consumer identity materializing there. In the following pages, however, this episode and its local (and) labour context are taken as starting points to attempt a further exploration and a more nuanced understanding of the relationship between work and consumption. On theoretical and empirical grounds, it is argued that, instead of conceiving work and consumption as separate and indeed opposite realms, a close link between them - with work providing a relevant context to the working person as a consumer, and consumption providing subjects a relevant arena where to perform the value of their work - should be acknowledged and scrutinized.

KEYWORDS: work, consumption, wage, manufacturing industry, factory closure, Portugal.
\end{abstract}

\section{WAVING FAREWELL TO THE INDUSTRIAL WORK (IN GEL NAILS)}

Ana $^{1}$ has decided to put on long, quite fancy gel nails shortly after becoming unemployed. Her former manual - though skilled - work as a machinist (afinadora de máquinas) prevented her from having long nails, either natural or artificial. She is now enjoying a new freedom.

It was one of the things that have occurred to me: well, ok, this is over, so I'll take care of my little nails, let's put some gel nails on [laughs]. Also, my fingers were dirty all the time - because of the oils and other chemicals 
in the needles, and in the machines as well... That's it: we were not entitled to go around in whatever adornment we wished to.

Listening to Ana's words - and looking at her hands - a shift from industrial to late (or reflexive, or liquid) modernity (Giddens 1991; Beck 1992; Bauman 2000) might appear to be materializing before us. Her once dirty, oily, naked hands, imposed upon her by work, are now freed from those constraints and ready to be made up according to her choice. Ana's hands (and herself) seem to have moved away from restriction to free will, from production to expression, from necessity to aesthetics. Or, as some would more briefly put it: from portraying a work-related identity to expressing a consumption-associated identity (Miller 1995; Ransome 2005).

However, as Ana goes on mentioning that, despite her newly acquired freedom, she has not resumed ring wearing (a one-time habit she had been forced to give up due to the material constraints of her job) continuity with her metalworker days starts to appear as a feature of her current beauty habits. This idea is reinforced as Ana gets across her thoughts on the changes to be forcibly introduced in her spending patterns by unemployment. Fitness gym attendance, professional hair and aesthetic care, frequent shopping for apparel and shoes, all are mentioned as part of a now threatened routine, leading us to begin suspecting that, far from representing a sharp rupture towards her former work, those conspicuous gel nails clearly fit in a set of consumption items Ana had put together in her metalworker days.

Thus, in this paper, Ana's gel nails, even if they appear at first to back some rather dichotomous assumptions on work and consumption, will contrariwise lead us to attempt a further exploration and a more nuanced understanding of the relationship between both. Literature on this relationship will be reviewed, with some mainstream, grand narrative contributions being contrasted with thematically more diverse, empirically grounded ones. Empirical material, drawn from an ongoing research on uses of work and consumption among women workers in a de-industrializing locality in Lisbon's commuter belt will then be presented and discussed. On those theoretical and empirical grounds, it will be argued that, instead of conceiving work and consumption as two separate and indeed opposite realms, a close link between them should be acknowledged and scrutinized - with work providing a relevant context for the working person as a consumer, and consumption providing subjects a meaningful arena where to perform the value they extract from their work.

\section{CONSUMPTION, WORK AND SUBJECT: GETTING INSIDE THE TRIANGLE}

Mass consumption, work (formal, waged work) and, more specifically, their changing mutual relation and their changing role and weight in peoples' lives 
have been awarded centre stage in a significant corpus of social theory contributions that discuss the contemporary world and the ways it compares to and has developed out of previous stages of modernity. A shift in the relative importance of work and consumption as identity and expression resources is indeed said to have occurred as part of the process that brought us to the contemporary world, and to remain as one of its hallmarks. Widely influential proposals by authors like Giddens (1991), Beck (1992) or Bauman (2000) depict a sharp withdrawal of old ties and narratives (work- and labour-related ones included), an ensuing identity void, pushing individuals into reflexive identity building exercises, and the arising of consumption as an irreplaceable arena of choice and self expression. ${ }^{2}$

This same point is reached, through a slightly different route, by Ransome (2005), who specifically focuses on the relationship between work and consumption. In his account, current Western contemporary societies' levels of affluence have provided subjects with an unprecedented ability to choose, i.e., to escape the restrictive borders of necessity. Therefore, expectations of satisfaction and pleasure have expanded, leading consumption to intensify not only quantitatively but, above all, qualitatively: a "new consumption" has developed, aimed at fulfilling the demand for ever novel sensations and experiences, and this in turn has stimulated the exploration and expression of self identities - an exploration to which, it is contended, the rather necessity-bound and monotonous work-based identities have very little to offer.

From a distinct theoretical position (and very far, namely, from endorsing any idea of a hedonistic consumer) Miller (1995: 42) finds in his understanding of contemporary consumption another avenue towards work's identitarian weaknesses. When discussing "consumption as the vanguard of history", the author enrols, among the features that have made consumption so, precisely the precedence as an identity resource that it (an exercise of autonomy) would have acquired over work (an experience of constraint).

Thus a privileged relationship is stated to exist between consumption and personal identity in present-day modernity. Particularly among the authors referred to above - Giddens, Beck and Bauman -, the argumentation of this relationship heavily rests on a strikingly matching characterization of both contemporary identification processes and contemporary consumption, the latter being primarily understood as an arena of choice that uniquely matches a reflexive self to whom the exercise of choice is quintessential. ${ }^{3}$ This point is

2 For recent critical reviews of Giddens, Beck and Bauman's proposals, especially regarding their demising of class analysis, see Atkinson (2007a, 2007b, 2008). For a critical assessment of their positions on "consumer's choice", see Warde (1994).

3 Warde (1994: 883, 897) highlights some political uses of the "consumer's choice" rhetoric. The use of consumption and consumers as "rhetoric devices" for theorizing about modernity is pointed out by Miller (2001: 2). 
worth noting because, since the work experience is inversely painted as a realm of insurmountable constringency - for, as Du Gay (1996: 88) has pointed out, "while exploding the myth of the 'passive consumer', cultural analysis institutes in its place the myth of the totally determined, deskilled worker" - then work is, by the same token, immediately disqualified as a resource for self building. Work and consumption come therefore to be seen not only as separate but even as sharply opposite, in content as well as in value, spheres of practice.

\section{People at work}

Two relevant bodies of research, however, directly or indirectly challenge this view. ${ }^{4}$ On the one hand, studies on work and workers continuously find out that subjects draw from their paid work more than the wage that allows them to engage in market mediated consumption. As Marx himself has noted, capitalist waged work implies but is not reducible to the worker's exploitation, to the monetary relationship between employer and employee. For the worker, to work is also to impact the world through "his own intelligent productive activity" (1961 [1867]: 310).

Going a step further, Bourdieu (1996) identifies a "dual truth of work": its "objective truth" as a field of economic exploitation, and its "subjective truth" as a field of subjective engagement. ${ }^{5}$ Such duality is posed as a necessary condition for work to be accomplished (and exploitation to occur), since subjective engagement would conceal the exploitative relationship. Similarly, Burawoy (1978) has found, through his seminal, ethnography-based research among North American metalworkers, that "consent" to exploitation is rooted in the "very limited but critical freedom [that workers enjoy] in their adaptation to the labour process [...] open[ing] up an area of choice" (Burawoy 1978: 199).

Whilst both Bourdieu and Burawoy see autonomy at work fundamentally as a lure for the workers (inherent to the labour process), more complex and ambiguous situations may arise. Among Portuguese glass-forming machine operators, a close relation was observed between, on the one hand, a marked awareness of the inescapably asymmetric power relations involved in waged labour and, on the other hand, an endless struggle for autonomy at work, against formal and informal factory regulations (E.M. Marques 2009). By means of their strived for and always precarious autonomy, workers attempt to take hold of as much (symbolic) value from their work as they can and to assert their refuse to act solely as mere producers of (monetary) value

4 Also, studies on the history of consumption dispute both the chronological marks and the marked dichotomies that support this narrative. For a recent discussion, see Trentmann (2009).

5 Bourdieu (1996) therefore finds the "Marxian labour theory" guilty of an "objectivist fault" for having failed to include the "subjective truth" of work in its analysis. 
to the employer's benefit. That their engagement with work frequently ends up creating extra such benefit (management hence overlooking most infringements), while being of course unable to effectively challenge the "objective truth of work", only underlines work's fundamental and ambiguous dual character, which sets the milieu and the limits to its subjective mobilization by the workers.

Work is subjectively mobilised, to take just a few examples, by engaging in struggles for autonomy and creativity in task definition and execution (Baba 1995; Lefebvre 1999; E. M. Marques 2009; Ruffier 1996; Terssac 1992), by otherwise setting a distance towards management and workplace formal rules, thus defining a reserved space within which work is construed as the workers' (Anteby 2003; Hatzfeld 2002; Molotch and McClain 2008), or by developing subjective identification with work tasks, values or contexts (Erikson 2002; Ibarra 2002; Jeudy-Ballini 2002; Monjaret 1996; Sherman 2005; Tornatore 1991). Bearing in mind the aforesaid constitutive ambiguity of those processes, it should be clear that the acknowledgement of their existence does not equal any assertion of generalised happiness or satisfaction at work (cf. Castillo 1997: 420-422), nor does it preclude the consideration of the substantial reshaping of waged work prompted by the last decades' emergence of neo-liberal flexible accumulation regimes, leading many to experience work as increasingly scarce, precarious, intensified, or stressing. Actually, most case studies in the above references directly deal with attempts to challenge, contest and adapt to this very transformation.

An analysis of workplace changes that simultaneously places a strong focus on consumer culture issues is provided by Du Gay's (1996) study of contemporary managerial attempts to mobilize UK retail workers' "consumer capital" (cf. Sassatelli 2007: 95-96) in order to enhance their engagement with corporate objectives and rules. Though expected to built their working selves upon their supposed consumer identity as calculating individuals, workers only limitedly seemed to espouse a view of their work as "an arena where people exhibit an 'enterprising' or 'consuming' relationship to self" (Du Gay 1996: 77), or to fit their understandings on autonomy at work with the company's. In this example, too, working people seem to have their own, autonomous belonging and engagement politics regarding work - and these work-related practices and narratives do not appear to have been so fully displaced by a consumer agenda as supposed, or desired.

Consistent with these observations, fairly recent empirical research (Doherty 2009; Garrett-Peters 2009; A.P. Marques 2009) persists on documenting the importance of work-related values and sociability in peoples' lives. For, if work has changed indeed, working subjects are still there. Research on people at work portrays them as active, engaged, struggling - even if suffering - subjects. It does not support the idea of a widespread cynicism or instrumentalism 
towards work, nor does it back the thesis of the end of work as an identity and expressivity arena. ${ }^{6}$

\section{Work(ers) and consumption}

A second (and far more heterogeneous) corpus of scholarship has been disputing the representation of work and consumption as polarities, by consistently finding multiple and complex links between both realms.

Long before contemporary theories of consumption, Halbwachs (1913) was among the first to examine such links. Analysing turn-of-the-century $\left(19^{\text {th }}\right.$ to $20^{\text {th }}$ ) German employees' and manufacturing workers' family budgets, he found in the latter a comparably low level of housing expenditure, further earnings being rather allocated to items like clothing and leisure. The author relates this under-spending in housing with an underdevelopment of family life, which he directly attributes to the manufacturing work conditions: people assigned by the social division of work mere execution tasks dealing with the material world would, in a sense, be expelled from society, therefore loosing their ability to sustain intensive social attachments, namely family ones (while achieving, on the other hand, an extensive class solidarity). Halfway between the a-social factory and the hyper-social family, "street sociality", or "class sociality", was preferred and cultivated through individual- (as opposed to family-) oriented consumption options, thus "explained by a radiating effect of the factory's working conditions over the worker's entire life condition" (Halbwachs 1913, book III: 48, my translation).

Characteristic as they are of Halbwachs' very own perspective on the materiality of manufacturing work and its "effects", these observations can nevertheless be fruitfully connected to Gartman's (1999) social history of labour process, consumer culture and class struggle in the automobile industry, since home and family also held a key position in his account of work and consumption among Detroit early twentieth-century auto workers. The intensifying and deskilling "scientifically managed" labour process then newly set up having initiated a huge wave of resistance, which threatened production and profit, automakers eventually implemented more rewarding wages and benefits as a convenient form of labour control. Not one that would spontaneously translate into the desired effects, however.

Ford was worried that workers imbued with the distinct working-class and immigrant cultures of the day would not spend their new wages 'wisely' but 'squander' them in traditional activities stressing mutuality, collectivity, and reciprocity $[\ldots]$ With the introduction of the new wage, Ford created 
the Sociological Department to encourage his workers to create a refuge of home-based consumption to compensate for the inhumanities of factory production. [...] Ford's offensive was part of the general cultural program of middle-class reformers and corporate capitalists during this period to break up what they perceived as the rowdy and unorganized culture of the working class, which often provided the basis for collective struggles. (Gartman 1999: 97) ${ }^{7}$

In this example, the setting of a borderline between work and consumption, and the resultant emergence of a seemingly (class-) unbound consumer, was by no means an artless process, that would evolve by itself out of a situation of relative worker's affluence. Rather it was a political endeavour, and certainly a class-bound one. ${ }^{8}$

Cohen (2001 [1993]) provides a complementary case study featuring worker lead uses of mass consumption. If, during the 1920s, Chicago workers had been introduced to mass consumption items mainly through their usual small local stores, in the following decade a diversity of convergent factors was to radically change their shopping environment. Facing the increasing number and market aggressiveness of chain stores, many independent ones went bankrupt, while those that managed to survive would make so by getting closer to the chain's ways of operation. Thus, a narrowing (not a widening) of options can be said to have occurred as a chief landmark in this particular path to mass consumption. And yet,

[...] a depoliticized working population who identified as middle class [...] did not emerge. Rather, mass consumption, as part of workers' increased involvement with mass culture, contributed to the development of a more homogeneous working-class culture, which helped build bonds among workers of different ethnic and racial groups [...]. (Cohen 2001 [1993]: 207-208)

Moreover, this cultural process, that was even instrumental to the formation of Chicago workers' unions, coexisted with an "ambivalence" of working-class people about their own adoption of chain stores. Workers "continued to harbor

7 In Gartman's view, however, workers eventually opted for mass consumption as a way of coping with an increasingly degraded labour process (1999: 97). The author then proceeds to a compelling discussion on the ways this adoption had in turn impacted production and the labour process itself.

8 Attempts to capture worker's consumer identity in order to enhance labour control and productivity, as studied by Du Gay (1996) can be seen as a looping closure of this process, as a way to still and further extract value from the old enterprise: once created as consumers, workers are now required to mobilise at work their consumers' skills. A step ahead is taken through the various schemes of "co-creation economy", which "is about experimenting with new possibilities for value creation that are based on the expropriation of free cultural, technological, social, and affective labor of the consumer masses" (Zwick, Bonsu and Darmody, 2008: 186; see also Foster 2008). 
a sense of being different, of being outside the maelstrom of 'mass consumption', and an awareness of the political significance of keeping consumption within working-class communities" (Cohen 2001 [1993]: 211).

Nowadays, in times of a well-established mass consumption, researches continue to be produced that highlight the influence of work-based self definition processes over consumption options. Freeman's (2000) study among female operators in the Caribbean data processing industry closely relates their dressing politics with an attempt to "emphasiz[e] the 'clerical' nature of her otherwise repetitive factory-like production" (Freeman 2000: 229). Holding low-paid yet high-status jobs (when compared to manufacturing or domestic ones) those operators use their "professional" look as a tool to appropriate and directly benefit from the symbolic value that the allure surrounding computer technology, together with the cleanliness and coolness of their workplace, build into the work they perform. That their dressing options are by no means a strictly "individual" matter is well illustrated by the professionally looking uniforms designed and proudly wore by a group of them (Freeman 2000: 220). ${ }^{9}$ Among those women, "the desire to 'dress hard' and sport the latest styles is also integrally bound up with their pink-collar identities as 'professional' employees in this new high-tech sector" (Freeman 2000: 226).

Not every situation appears that clear, however. Rothstein's (2005) research on social change and consumption in a once peasant turned into petty industrial Mexican town portrays a place where work-based identities have been made difficult to activate by the very flexible accumulation productive structure (characterized as it is by an amalgam of family and labour relations and by subcontracting). Even so, consumption practices that look as if they were increasingly the sole result of individual options and agendas come to reveal, when carefully scrutinized, a close relation to those systemic conditions.

\section{WORK, CONSUMPTION AND PLACE}

\section{The making of an industrial place}

Ana's factory, a German-owned unit manufacturing precision components for textile and leather machinery, had started operations by $1969,{ }^{10}$ after the erection of dedicated premises on former agriculture fields.

Some 20 kilometres west of Lisbon and a few inland, this was a windy, unforested district, where poor soils and a severe lack of water only allowed for a non-irrigated agriculture, plus some cattle and sheep rearing (Silva 1969).

9 This is an example that does not support the idea of a privileged link between self identity and individual choice.

10 Preliminary works (hence some labour contracts) started in 1968. The factory was launched by a North-American company that sold it to the German group in 1982. 
Many local men (and boys) would switch between (mostly seasonal) farming jobs and stone work, in quarries scattered throughout the area. Both activities had for long entailed dynamic links with Lisbon, and with the nearby coastal strip. The second, where a sun-, sea- and gambling-based tourism industry, more or less exclusive housing developments and (latter on) commuter towns of various sorts would all noticeably expand during the $20^{\text {th }}$ century, offered some consumption market for the local farming and stone industries, and a labour market for local people, consisting mainly of construction jobs for men and domestic jobs for women. ${ }^{11}$ Along the 1960s, the burgeoning development of the coastal fringe, together with the vanishing economic viability of local agriculture and stone extraction, strengthened this pattern of dependence towards more affluent places.

Yet, workshops and factories were also being locally set up whose expansion soon would change this picture (Silva 1969: 58-66). By 1956, precisely in order to preserve the coastal area and landscape for high-value tourism and housing uses, the Cascais municipality (in which territory we are) had decided to push inland the ailments of manufacturing, by defining there a perimeter for industrial development (Pereira 1994: 106). Given the ensuing availability of cheap industrial land, as well as the presence of what were then considered good road links to Lisbon (hence to air and sea cargo transportation facilities), a slice of the Lisbon's industrial belt, then in expansion, was eventually settled in the area. The resulting availability of stable and relatively well-paid manufacturing jobs, in a full-employment situation, ${ }^{12}$ the skilled character of some of these jobs, the diversity of production sectors featured, the presence of foreign investment and management, the export-oriented character of some firms, the demographic growth (with rural migrants arriving in increasing numbers), the changed landscape - all amounted to the creation of a new place. Foretold by $1968 / 69$ as the most important local manufacturing unit, especially in staff dimension (Silva 1969: 64) - a promise kept until the end of the century - the factory where Ana would latter become a mechanist fully embodied the new times, turning out to be emblematic of this place making process.

Place making, as Gupta and Ferguson (1997: 6) conceive it, is "a social and political process $[\ldots]$ of embodied practices that shape identities and enable resistances". Through the production of an industrial work-based place, this

I Also, a number of skilled workers daily commuted to Lisbon's stone workshops. Written sources document local early $20^{\text {th }}$ century stone workers class organizations, affiliated with nation-wide trade unions (Teixeira, Cardoso and Miranda 2003: 221 ff.; Sabido 2003).

12 The colonial war (1961-74) and the 1960s significant Portuguese emigration were then allowing a full employment situation in industrial development sites like this one - whereas in rural settings unemployment and labour precariousness continued to be the rule. In a few years, the generalised wage rise following the 1974 Carnation Revolution would further boost manufacturing working-class condition. 
was not anymore the subordinate space to where manufacturing industry was pushed out, but the place where such industry and, most importantly, industrial work were appropriated by the locals/workers as a material and symbolic resource from which to construct specificity and autonomy - with consumption practices playing a significant part in the process.

Data of various kinds substantiate the place's specificity. The industrial job offer partly supported demographic growth rates higher than the whole municipality's along the 60s, 70s and 80s. ${ }^{13}$ In contrast, formal education levels were and remain considerably lower than the municipality's average. ${ }^{14}$ As an exception to the rather right-wing Cascais area, a socialist majority rules the governing bodies of the relevant freguesia ${ }^{15}$ (up to 1993 there was even a communist majority). The local representation of the place as a labour and working-class island amidst a rather bourgeois area pervades popular culture, as in these verses from a local author: "For the Cascais municipality/ It [this freguesia] is the most important asset/ Since it is the most valuable [of all freguesias]/ It is the headquarters of labour" (Rianço 1996), corroborating Narotzky and Smith's warning against the assumption "that sentiments of place-belongingness glossed as 'community' and those as collectivities in terms of class are mutually exclusive" (2007: 212). Industrial facilities, together with vast neighbourhoods of simple houses, mostly built during the 1970s, with no legal permission nor land planning, came to materialize the place's locality, amounting for the most salient elements in a rather patchwork-like, dissonant landscape. Inside those neighbourhoods, signs reading "Labour's Day Street", "People's Street", "Factory's Street" or "Worker's Street", ${ }^{16}$ among others, explicitly inscribe locality into the physical territory and (not the least) into its organizing representations.

\section{"Freedom originated in the factory"}

By quarter to noon, Berta (one of Ana's former co-workers, who got unemployed two years earlier), excuses herself for starting lunch preparation during our interview, that is taking place in her kitchen. She and her husband, a childless couple who have met in the factory, still maintain their working days meal schedule, in spite of having left their jobs for years now. They also keep vivid memories of work. Berta, who worked mainly as a machine operator, but also as a packaging operator, describes her 33-years career within the factory,

13 Demographic growth has continued to be observed after the 1980s, but then as part of Lisbon's commuter belt sprawl dynamics.

14 A comprehensive corpus of local statistical data was compiled by Perista and Silva (2009).

15 Freguesias are the smallest Portuguese local governance units. They are grouped into municipalities (concelhos). Since the 1974 Revolution, all local governing bodies are selected through democratic election. 16 Rua 1. de Maio, Rua do Povo, Rua da Fábrica, Rua do Operário. Some of those names are found in several neighbourhoods. 
circulating through numerous positions (a fact that gave her a thorough knowledge of the production process and a wide range of working skills) and stresses how strict she was when training younger fellow workers, "because I liked well done work". Describing tasks in a detailed way, recalling the production of the needles with which Euro Cup soccer balls were sawn, or considering that, unlike the workers', engineers' knowledge was useless for actual production, are some other ways Berta finds out to express representations of her work as skilled and valuable. But no less present in her words, however, is the comfortable pay she used to get, or how easy it was to find and keep a good job in her young woman's days.

In another occasion, Clotilde, a former quality inspector (in the same factory between 1969 and 2007) is reading to me across a 1999 factory newsletter featuring short interviews with the most senior workers. A quotation as "I've started with a 1600 escudos ${ }^{17}$ wage and a promise of 1800 in two months if things went right; as everything went really well, in two months I was earning 2000" causes her to burst into tender laughs, while another colleague's words on seniority with the firm - "next month I'll be 31 years with the company" - make her say, "I'm even shivering!"

In these examples, subjective engagement with work and a pragmatic, instrumental attitude towards it clearly appear not to be mutually exclusive. On the contrary: the very instrumental character of work, the precise fact that waged work provides indispensable resources both for living and for making sense of life, is in itself a factor (though by no means the only one) of subjective engagement towards it. Conversely, a good wage substantiates one's worth as a worker. An intricate weaving of statements of "pride", "responsibility" or "proficiency" (interviewees' words) regarding work, minute, enthusiastic descriptions of work products, procedures and ambiences, expressions of deep sorrow for the factory closure, and, on the other hand, frequent references to a good wage and a stable job, is a remarkable feature in these narratives, and one which is worth noting for the present discussion. These women value satisfaction at work, while keeping a lucid awareness of their proletarian condition, which makes them deserving a wage (since they produce material wealth for others, they should not be paid mere symbolic value), and being in need of one. ${ }^{18}$ Work's material and symbolic value are jointly assessed.

Dora, also a former quality inspector (in the factory from 1974 to 2007), provides another telling example of such connection when she compares women's work in manufacturing with housekeeping work:

17 The escudo was the Portuguese pre-euro currency.

18 The difficult balance between job satisfaction and wage satisfaction is captured in these words from a male machinist who got unemployed by factory closure and has so far found but minimum wage jobs in his search for a new position: "Without a wage, you're nothing. There can even be some [poorly paid] job I really love to do, but I must take care of my family first and then look after myself." 
A housekeeper: sure she gets her pay, sure her work is worthy, but she was looked at differently. Little domestic tasks, isn't it? Not so in the factory. There, women had to face co-working with men, having a schedule to follow, that was completely new. But women started to feel free. There began women's freedom [...] Freedom originated in the factory. I've felt it myself [...] I would think: I work my eight hours schedule, then I have my own time, and at the end of the month I'll touch a guaranteed amount [... Women began to feel more responsible. I've felt it.

Responsibility and freedom, skilfulness and wage, deeply intertwine in this account of work as empowerment. Altogether, an idea of control over one's job and income, a representation of work as a needed and available material and symbolic resource, pervade these narratives. ${ }^{19}$ And this feeling of empowerment obviously reinforces subjective engagement towards work. Clotilde whose oldest daughter is now unemployed - sums up: "It was a very good life, with work."

\section{"Could ever a housekeeper possibly look like one of us?"}

Work and good life fully meet in these workers' narratives on consumption. The connection between wage and access to meaningful consumption is straightforward in their words, when referring both to daily consumption routines and to extraordinary consumption instances.

My husband is a plumber, he worked every day, Saturdays included [...] On Saturdays, he received his pay immediately. And my husband would come back home and say: 'get the girls ready and let's go eating out'. And what did the younger one like to have? An edible crab [sapateira]! And my husband would make a point of working [on Saturdays] to pay his daughter her edible crab. [Clotilde]

Without a doubt, these edible crabs are bestowed with meanings of good fatherhood and family harmony. But it is no less obvious that such meanings are absolutely inseparable from the crab's condition of expensive commodity, and from the ensuing feat of being able to afford it as a treat while being not wealthy, only through one's work. A wage is obviously not like any other income, for it embodies the value of work and the worth of the worker - that, in those episodes, so immediately and visibly turned into meaningful consumption. It is this clarity, together with the (explicitly mentioned) fact that

19 A permanent labour contract, a never disrupted paying schedule, the convenience of a close-tohome job and the possibility of work a three-fold waged extra work time, all amounted to these workers' empowerment towards and at work. 
turning her husband's Saturday work into a "superfluous" consumption practice was only possible thanks to her adding a wage to the family budget, that assigns edible crabs a very special place in Clotilde's work memories.

Among these women, the link is also clear between earning a wage and feeling entitled to enjoy some beauty habits. Hairdressing, face making-up, perfume wearing, and keeping an eye on apparel and shoe trends are all mentioned. Elisa, who entered the factory in 1974 and stayed for 30 years, having preferred manufacturing work over her previous occupation as a freelance hairdresser, and who repeatedly insists on the high-responsibility character of her "attractive" (her word) work as a final quality inspector, recalls the Burda fashion magazine she would purchase and share with colleagues, and enthusiastically describes the phone calls from a friend working in Lisbon, letting her know that fabric sales were taking place there and the ensuing collective shopping trips to the Chiado department store (and to nearby cake shops as well).

Besides Lisbon, towns in the nearby coastal lane (Carcavelos, Parede, even Cascais) were also elected as shopping destinations - in a full reversal of the old dependency dynamics. If, formerly, people would go out in search of the indispensable monetary resources they could not find locally, now those women went out to gel hold of a higher rank of goods than those locally available, and were able to reach them through locally originated resources.

Elisa's shopping trips with colleagues mostly dealt with the selection and purchase of fabric to be later made into outfits by local seamstresses. By the very beginning of the Portuguese 70s, available ready-made apparel still consisted mostly of substandard items, deserted by fashion - while the gathering of a fabric from Chiado, a design from Burda and a skilled seamstress was likely to result quite fashionable, and this well into the middle classes. Ready-towear garments, however, were soon to get centre stage in all quality ranges, and these workers were taking the move. Fernanda, a quality control team leader (in the factory from 1969 to 2005) who fully complied with the custom of handing her salary to her mother till wedding day, remembers some specially cherished items: a fashionable bright pink knit dress her mother once bought her at the Cascais market, and some quite chic garments from a downtown Lisbon bourgeois shop.

Every time my salary was raised I was anxious to get back home to tell my mother! [...] I've bought a coat to attend a wedding party [...] It cost me 2400 escudos $^{20}$ - I was still unmarried - 2400 escudos, a coat! It was at Eduardo Martins. But the coat was gorgeous (I've thrown it away a short

20 The coat was priced 2400 escudos or, as she says, "dois contos e quatrocentos". If applying the appropriate official currency devaluation coefficient (Portaria n. ${ }^{\circ} 772 / 2009$, de 21/07, DR Série I, n. ${ }^{\circ}$ 139), a $€ 260$ sum would result. As of January 2010, the Portuguese minimum wage equals $€ 475$. 
time ago) it was lovely, pink, a close-fitting, waisted coat. I was thin [...] I went shopping with my mother, she paid for it, for I've always given her my wage. And a lady in a shop who saw me passing by even went peek at the door. She didn't know who I was, but she went peek and later on she told me I was quite well dressed!

Acceded through work, these consumption practices conversely appear as favoured tools when constructing self as a manufacturing worker. For instance, among the women who had started work during the late 60s or the 70s, hairdressing was usually a weekly ritual, scheduled in order to allow an irreprehensible look when returning to the factory every Monday. Good look techniques and items were instrumental in the making of a very sought after distance towards women working in farming or in housekeeping ("Could ever a housekeeper possibly look like one of us? No way, there was a remarkable difference!" - says Clotilde), while simultaneously claiming proximity between manufacturing and white collar women workers ("I was working on the shop floor, but many thought I was in the office" - says Dora). Thus work allows access to consumption, while simultaneously providing a particular environment for consumption options to unfold. Work, income, consumption of beauty items and self image as a worker profusely interact.

I was proud of working and of getting out every morning, of taking care of my look - something I don't do now. Those days I would get hairdressing every week [...] We would wake up in the morning, have a shower, face make-up, and off to our work we went. But it was different [from now], we were getting our wage. [Clotilde]

\section{The end of an industrial place: elusive work, elusive consumption}

They are no longer getting their wage. All have become jobless well before retirement age, during the factory's downsizing years. And though cushioned, for some time, by an alternative income (a job loss compensation plus a monthly unemployment allowance),${ }^{21}$ they have thus been forced to adjust some quite meaningful consumption practices. Hence, Berta now mobilises the tailoring skills she acquired in her "pre-industrial", young girl days to make her own

21 Portuguese labour law ensures employees holding permanent labour contracts a job loss compensation amounting to one month wage per working year. In this factory, both during downsizing and at closure, job loss compensations have been calculated on a 1.5 factor. Social security granted unemployment allowances are calculated upon the last wage (sometimes, as it is the case with those workers, the net amount is similar). They are granted for a variable period, depending on age and seniority with the firm. People receiving an unemployment allowance are required to "actively seek" a new job, which actually translates into "going for stamps": filling in a form where prospect employers testify, through their official stamps, having received (and refused) a job demand. 
clothes. Elisa, whose fancy house "was the dream of my life", overvalues past issues of home-decoration magazines she used to purchase when employed and cannot afford anymore. Clotilde has given up attending professional hairdressing.

The same injunction is faced by Ana. Having entered the factory in 1999 as a machine operator, at closure time (January 2009) she was one of the few (11 out of 59) women machinists - a function she recalls as a "non-routine, not monotonous, cool" job (her words), getting hold of which had cost her considerable exertion, in order to acquire both the required technical skills and her male fellow workers acceptance.

From this strived for, relatively well paid, skilled, high-responsibility work, Ana used to extract material and symbolic value that is no longer plainly available to her. Yet, embodied in memories, gestures, habitus - consumption ones included - construed along ten years in the factory, such value is not to abruptly disappear either. Its stubborn endurance, backed by an alternative income (similar to her older colleagues') which indeed represents the temporary survival of the lost employment relation, has allowed Ana her gel nails - as well as a laptop (once she is now completing secondary school) and a number of homedecoration items, whose selection and assembling had assisted her in killing some suddenly so plentiful time. The symbolic link between these consumption options and Ana's past work would be more understandable in view of her opinion that unemployed people who do not rush to find a new job are not behaving unethically, because to benefit from the entire unemployment allowance period is "our right" (her words) as former workers. Thus it is still through work that Ana feels entitled to access those meaningful consumption items.

Although she is now wondering how to possibly live on half her usual income (for a minimum wage pay is the only realistic expectation she can harbour regarding a next job), the truth is that Ana's former two minimum wages salary did not itself match the remuneration patterns once enjoyed by her older colleagues (who accordingly report a decreasing purchasing power in their later days at the factory). A married woman with an only child, she refers that eating out regularly or enjoying a real holiday with no housework have never been real options, and that her fondness on shopping for clothes had to be satisfied mostly through low cost sources. More skilled, yet less affluent, Ana lives in the low cost age. Interestingly, she even finds a relation between the company's option of "competing with China" (her words), getting a foot also on low cost markets, and the eventual factory closure. Anyway, "it was not a rigorously working factory anymore", Elisa recalls. "Lately, production was a mess. Some defects started to be acceptable, they [the bosses] would not care [...] I would not even know how to work anymore", Clotilde complains. The manufacturing work-based locality where they had lived, worked and consumed for decades was eroding, literally in their hands. 
Understanding its making and unmaking requires bearing in mind the capitalist labour relations framework within which it has evolved. While being intrinsically mobile, economic capital nonetheless must embed in locality if it is to operate (Burawoy 2000: 345). Production is delocalized from somewhere only for being re-localized elsewhere, the (changing) local conditions of profitability obviously mattering. Thus the settlement of Ana's factory in 1968 cheap labour Portugal, the sharp growth of its workforce during the 90s EU co-funded Portuguese industrial development and occupational training programs, and its eventual relocation in 2009 newly EU funded Czech Republic are part of the same process. At each locality, "moral economies of the workplace" develop, out of the encounter between corporate strategies and local conditions and expectations (Collins 2003: 12-13). In the near full employment conditions of the local industrial outbreak, as well as in the post1974 revolution political and ideological environment, such "moral economy" included what was felt by the workers as good wages (while still being cheap labour from the corporate point of view). It also included, and never ceased to include, collective bargaining and labour organization and struggle, whose influence was considerable in the shaping of the remuneration and working (and job loss compensation) conditions. In more recent times of flexible accumulation ideologies and practices, this moral economy of work changed to accommodate lower pay, increased work pace, workforce downsizing, quality downgrading and, eventually, plant closure.

Gone are the transient times of manufacturing industry. Abandoned industrial premises, dusty expecting areas, speculation-driven developments aimed at commuters, pedestrian hostile, ever busy roads (for an increase in circulation escorts the weakening of locality) and low cost retail supermarkets now add to the physical and social landscape of a once manufacturing work-based place. While commenting with Dora and Fernanda on writing a study on the local industrialization, they supported the idea on the grounds that a time when work was rewarding and (connectedly) peoples' lives were improved, certainly deserves recording. Sandwiched between "pre-industrial" poverty and today's unemployment and precariousness, those were times now remembered as affluent, entailing memories of proletarian work, wage and consumption.

\section{CONCLUDING REMARKS}

Built, too, on local specificities, the "moral economies of workplace" conversely pervade locality beyond the factory, closely relating to and co-shaping, namely, consumption practices and narratives. Moral economies of work and consumption would certainly be an apt notion to convey the ways people in the above discussed case connect both realms, for moral values like fairness, entitlement, exertion, appear to be paramount there. 
If the reviewed literature has provided plenty of material on the diverse, active links between work and consumption, two particular forms of such links have emerged from the original example: work as a valid context for the working person as a consumer; and, connectedly, consumption as an arena where to perform the material and symbolic value obtained from one's work.

Appadurai (1995: 213) puts forward an idea of context as "the frame or setting within which various kinds of human action (productive, reproductive, interpretive, performative) can be initiated and conducted meaningfully". This assigns context a role as co-creator of meaning, favouring relation over essence - a quite relevant stance regarding such a relational practice as consumption. "All goods carry meaning, but none in itself $[\ldots]$ the meaning is in the relations between all the goods", Douglas and Isherwood (1979:49) remarked. For instance, the particular meaning of Fernanda's very expensive coat is inseparable from the generally not sumptuous ensemble of her wardrobe; in another closet, the same coat would mean differently. But relation and not essence make each person's specificity as well. The idea of consumption as an encounter (and a making) of subject and object specificities was put forward by Miller (1987) against the received wisdom of mass consumption as an endless replication of alike people robotically consuming alike goods. The connection of both ideas (on relation and on specificity) entails the acknowledgement that one's position(s) in the social world - to which work seriously matters - weights right in the heart of subjective and expressive consumption.

Thus contributing to one's social and subjective definition, work further contextualizes the working person as a consumer by providing him, or her, the material (and some symbolic) means to access it. The wage brings work into consumption. Could the way appropriation occurs not be contingent, certainly among other things, on the effort (or lack thereof) made to get the item, on the way it was reached for, on its routine or exceptional, need or treat (or both simultaneously) character as evaluated by the consuming person?

The role of consumption as a politics of social positioning is widely acknowledged by the social sciences and - importantly - by common sense as well. Particularly focusing mass consumption by the non-powerful, several authors went a step further, identifying there clear expressions of social struggle. Thus Narotzky and Smith (2007: 167) assert consumption as a mediating expression of "inclusion in the broader social world". Carrier and Heyman (1997: 356) stress the inequality conditions in which consumption occurs, while Miller, though recognizing such conditions, also points to the "morality of egalitarianism" that consumption is able to support (1995: 42). Following Castells' view of consumption as a secondary ground for the production-initiated class struggle, García Canclini (2001: 39) proposes in turn that "to consume is to participate in an arena of competing claims for what society produces and the 
ways of using it" - an insight shared by Rothstein (2005: 300) when analysing changes in consumption among her Mexican subjects. Ethnography in this text supports and illustrates these arguments, while specifically suggesting a close relation between "claims" for inclusion and sharing, expressed through consumption, and work's material and symbolic value. Within these particular moral economies, work provides the value to be "claimed", and consumption is wanted to be accessible enough to allow the value of work to be substantiated, performed and rightfully enjoyed. ${ }^{22}$

A kind of happy fitness between a feeling of entitlement to a certain array of consumption goods and the ability to reach them through one's work is visible in the way workers in this study remember a transient time and place of near full employment and stable jobs - contrasting with narratives of refrain and unease when current low cost times are referred to. Place has been remade and the prevalent moral economies of work and consumption have changed. In spite of this, however, work, consumption and the relationship between both still do not fit the mainstream narratives of work as a meaningless, identity deserted, merely instrumental chore, of consumption as an exercise of more or less unbound, individual choice and of both as independent from each other. Deeply place-, position- and history-rooted, consumption appears in this example as a way for people to claim the value of their work, while maintaining full awareness of their waged - or unemployed - worker condition. No one would ever consume (or perform any other relational practice, for that matter) out of their contexts of practice and meaning, and work certainly qualifies as such when material and symbolic access to consumption are considered. It is on these grounds of context-rooted meaning, not on the rank of service and price they are able to reach, that people in this study can be said to consume as workers - be it Clotilde having an expensive edible crab or Ana wearing fancy gel nails.

22 Miller's $(1987,1995)$ concept of consumption as a realm where the alienation initiated in production and distribution can be overcome through creativity and specificity must be mentioned at this point for, in spite of its distance from the just mentioned proposals, it shares with them an idea of consumption as a kind of reparative practice regarding some social and subjective damage originated in the spheres of economy and production. 


\section{REFERENCES}

ANTEBY, Michel, 2003, "La 'perruque' en usine: approche d'une pratique marginale, illégale et fuyante", Sociologie du Travail, 45 (4): 453-471.

APPADURAI, Arjun, 1995, "The production of locality", in Richard Fardon (ed.), Counterworks: Managing the Diversity of Knowledge, London and New York, Routledge, 204-225.

ATKINSON, Will, 2007a, "Anthony Giddens as adversary of class analysis", Sociology, 4 (3): 533-549.

—, 2007b, "Beck, individualization and the death of class: a critique", British Journal of Sociology, 58 (3): 349-366.

— 2008, "Not all that was solid has melted into air (or liquid): a critique of Bauman on individualization and class in liquid modernity", The Sociological Review, 56 (1): 1-17.

BABA, Marietta, 1995, "Work and technology in modern industry: the creative frontier", in Frederick C. Gamst (ed.), Meanings of Work: Considerations for the Twenty-First Century. Albany, SUNY, 120-146.

BAUMAN, Zigmunt, 2000, Liquid Modernity. Cambridge, Polity.

BECK, Ulrich, 1992, Risk Society: Towards a New Modernity. London, Sage.

BOURDIEU, Pierre, 1996, "La double vérité du travail", Actes de la Recherche en Sciences Sociales, 1 14: 89-90.

BURAWOY, Michael, 1978, Manufacturing Consent: Changes in the Labor Process under Monopoly Capitalism. Chicago, University of Chicago Press.

—, 2000, "Grounding globalization”, in Michael Burawoy (ed.), Global Ethnography: Forces, Connections and Imaginations in a Postmodern World. Berkeley, University of California Press, 337-350.

CARRIER, James G., and Josiah McC. HEYMAN, 1997, "Consumption and political economy", JRAY (n. s.), 3: 355-373.

CASTILLO, Juan J., 1997, "Looking for the meaning of work", Work and Occupations, 24 (4): 413-425.

COHEN, Lizabeth, 2001 [1993], “The class experience of mass consumption”, in Daniel Miller (ed.), Consumption: Critical Concepts in the Social Sciences. London and New York, Routledge, vol. IV, 195-218.

COLLINS, Jane L., 2003, Threads: Gender, Labour and Power in the Global Apparel Industry. Chicago, University of Chicago Press.

CORSÍN JIMÉNEZ, Alberto, 2003, "Working out personhood: notes on 'labour' and its anthropology", Anthropology Today, 19 (5): 14-17.

DOHERTY, Michael, 2009, "When the working day is tough: the end of work as identity?", Work, Employment and Society, 23 (1): 84-101.

DOUGLAS, Mary, and Baron ISHERWOOD, 1979, The World of Goods: Towards an Anthropology of Consumption. Harmondsworth, Penguin.

Du GAY, Paul, 1996, Consumption and Identity at Work. London, Sage.

ERIKSON, Philippe, 2002, “'Tout ce qui ferait fuir un âne': L'amour du métier chez les électriciens du bâtiment", Terrain, 39: 69-78.

FOSTER, Robert, 2008, "Commodities, brands, love and kula: comparative notes on value creation, in honor of Nancy Munn”, Anthropological Theory, 8 (1): 9-25.

FREEMAN, Carla, 2000, High Tech and High Heels in the Global Economy: Women, Work, and Pink-Collar Identities in the Caribbean. Durham, Duke University Press. 
GARCÍA CANCLINI, Nestór, 2001, Consumers and Citizens. Minneapolis, Minnesota University Press.

GARRETT-PETERS, Raymond, 2009, “'If I don't have to work anymore, who am I?' Job loss and collaborative self-concept repair", Journal of Contemporary Ethnography, 38 (5): 547-583.

GARTMAN, David, 1999, "Dialectics of the labor process, consumer culture, and class struggle: the contradictory development of the American automobile industry", in Mark Wardell, Thomas L. Steiger and Peter Meiksins (eds.), Rethinking the Labor Process. Albany, SUNY: 93-109.

GIDDENS, Anthony, 1991, Modernity and Self-Identity. Cambridge, Polity Press.

GUPTA, Akhil, and James FERGUSON, 1997, "Culture, power, place: ethnography at the end of an era", in Akhill Gupta and James Ferguson (eds.), Culture, Power, Place: Explorations in Critical Anthropology. Durhan, Duke University Press, 1-30.

HALBWACHS, Maurice, 1913, La classe ouvrière et les niveaux de vie: recherches sur la hiérarchie des besoins dans les sociétés industrielles contemporaines. Paris, Alcan.

HATZFLED, Nicolas, 2002, "La pause casse-croûte: quand les chaînes s'arrêtent à PeugeotSochaux", Terrain, 39: 33-48.

IBARRA, María de la Luz, 2002, “'Creen que no tenemos vidas’: mexicana household workers in Santa Barbara, California”, in Ann E. Kingsolver (ed.), More than Class: Studying Power in US Workplaces, 148-172.

JEUDY-BALLINI, Monique, 2002, “'Et il paraît qu'ils ne sont pas tous sourds?' Le travail comme exploit et résistance au quotidian”, Terrain, 39: 17-32.

LEFEBVRE, Bruno, 1999, “Techniques, robots et chaînes opératoires”, in Jean-Luc Jamard, Anie Montigny and François-René Picon (eds.), Dans le sillage des techniques: Hommage à Robert Cresswell. Paris, L'Harmattan, 333-347.

MARQUeS, Ana P., 2009, Trajectórias Quebradas: A Vivência do Desemprego de Longa Duração. Porto, Profedições.

MARQUeS, Emília M., 2009, Os Operários e as Suas Máquinas: Usos Sociais da Técnica no Trabalho Vidreiro. Lisboa, Gulbenkian/FCT.

MARX, K., 1961 [1867], Capital: A Critical Analysis of Capitalist Production (1887 translation, by Samuel Moore and Edward Aveling, edited by Friedrich Engels). Moscow, Foreign Languages Publishing House, vol. I.

MILlER, Daniel, 1987, Material Culture and Mass Consumption. Oxford, Blackwell.

—, 1995, "Consumption as the vanguard of history: a polemic by way of an introduction", in Daniel Miller (ed.), Acknowledging Consumption. London, Routledge, 1-57.

—, 2001, "Introduction", in Daniel Miller (ed.), Consumption: Critical Concepts in the Social Sciences. London and New York, Routledge, vol. I, 1-14.

MOLOTCH, Harvey, and Noah McCLAIN, 2008, "Things at work: informal social-material mechanisms for getting the job done”, Journal of Consumer Culture, 8 (1): 35-67.

MONJARET, Annie, 1996, “'Être bien dans son bureau': jalons pour une réflexion sur différentes formes d'appropriation de l'espace de travail”, Ethnologie Française, XXVI (1): 129-139.

NAROTZKY, Susana, and Gavin SMITH, 2007, Immediate Struggles: People, Power and Place in Rural Spain. Berkeley, University of California Press.

PEREIRA, Margarida, 1994, O Processo de Decisão na Política Urbana: O Exemplo da Costa do Sol. Lisbon, UNL, Geography PhD dissertation, unpublished. 
PERISTA, Heloísa, and Alexandra SILVA, 2009, Diagnóstico Local da Igualdade de Género (Cascais). Lisboa, CESIS, mimeo.

RANSOME, Paul, 2005, Work, Consumption and Culture: Affluence and Social Change in the Twenty-First Century. London, Sage.

RIANÇO, Natael, 1996, Escrevo ao Sabor da Pena. Cascais, Associação Cultural de Cascais.

ROTHSTEIN, Frances A., 2005, "Challenging consumption theory: production and consumption in Central Mexico”, Critique of Anthropology, 25 (3): 27-306.

RUFFIER, Jean, 1996, L'efficience productive: comment marchent les usines. Marseille, CNRS.

SABIDO, José L. T., 2003, Tires, Terra de Canteiros. São Domingos de Rana, Junta de Freguesia de São Domingos de Rana and Associação Cultural de Cascais.

SASSATElli, Roberta, 2007, Consumer Culture: History, Theory, Politics. London, Sage.

SHERMAN, Rachel, 2005, "Producing the superior self: strategic comparison and symbolic boundaries among luxury hotel workers", Ethnography, 6 (2): 131-158.

SILVA, Maria M.M., 1969, Abóboda e Trajouce: Aldeias Suburbanas em Transformação, Lisbon, FLL, Geography graduation dissertation, unpublished.

TEIXEIRA, Carlos A., Guilherme CARDOSO, and J. MIRANDA, 2003, Registo Fotográfico da Freguesia de São Domingos de Rana e Alguns Apontamentos Histórico-Administrativos. Cascais, Câmara Municipal de Cascais.

TERSSAC, Gérard de, 1992, Autonomie dans le travail. Paris, PUF.

TORNATORE, Jean-Louis, 1991, "Être ouvrier de la navale à Marseille: technique(s), vice et metier", Terrain, 16: 88-105.

TRENTMANN, Frank, 2009, "Crossing divides: consumption and globalization in history", Journal of Consumer Culture, 9 (2): 187-220.

WARDE, Alan, 1994, "Consumption, identity-formation and uncertainty", Sociology, 28 (4): 877-898.

ZWICK, Detlev, Samuel K. BONSU, and Aron DARMODY, 2008, "Putting consumers to work: 'co-creation' and new marketing govern-mentality”, Journal of Consumer Culture, 8 (2): 163-196.

Valor e expressão do trabalho, do salário e do consumo entre mulheres operárias - Emília Margarida Marques • CRIA/ISCTE-IUL; FCT post-doctoral grantee, Portugal • em.marques@fcsh. unl.pt

Perante uma ex-operária que decide aplicar unhas de gel pouco depois de perder o emprego (cujas circunstâncias materiais lhe limitavam o arranjo das mãos), algumas influentes teorias da contemporaneidade encontrariam o exemplo acabado da transição de uma identidade operária, constrangida pelo trabalho, para uma identidade pós-trabalho, construída nas livres escolhas de consumo. Neste texto, porém, esse episódio e os respectivos contextos local e laboral são tomados como ponto de partida para uma exploração mais aprofundada das complexas relações entre trabalho e consumo. É criticada a ideia de separação, ou até oposição, entre ambos os campos de prática, propondo-se, pelo contrário, o reconhecimento e a discussão das suas estreitas ligações - designadamente, a presença do trabalho como contexto relevante para o trabalhador enquanto consumidor e a importância do consumo como lugar de expressão do valor do trabalho.

PALAVRAS-CHAVE: trabalho, consumo, salário, indústria, encerramento de fábricas, Portugal. 